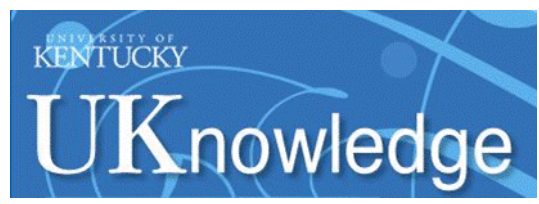

University of Kentucky

UKnowledge

6-18-2019

\title{
Developing Numeracy and Problem-Solving Skills by Overcoming Learning Bottlenecks
}

Anita Lee-Post

University of Kentucky, Anita.Lee-Post@uky.edu

Follow this and additional works at: https://uknowledge.uky.edu/marketing_facpub

Part of the Higher Education Commons, and the Science and Mathematics Education Commons Right click to open a feedback form in a new tab to let us know how this document benefits you.

\section{Repository Citation}

Lee-Post, Anita, "Developing Numeracy and Problem-Solving Skills by Overcoming Learning Bottlenecks" (2019). Marketing \& Supply Chain Faculty Publications. 5.

https://uknowledge.uky.edu/marketing_facpub/5

This Article is brought to you for free and open access by the Marketing \& Supply Chain at UKnowledge. It has been accepted for inclusion in Marketing \& Supply Chain Faculty Publications by an authorized administrator of UKnowledge. For more information, please contact UKnowledge@lsv.uky.edu. 


\title{
Developing Numeracy and Problem-Solving Skills by Overcoming Learning Bottleneck
}

\author{
Anita Lee-Post \\ Gatton College of Business and Economics \\ University of Kentucky \\ Lexington, KY 40506
}

\begin{abstract}
We present an educational approach to elevating problem-solving and numeracy competencies of business undergraduates to meet workplace demand. The approach is grounded in the theory of constraints following the Decoding the Discipline model. We investigated a cognitive bottleneck involving problem modeling and an affective bottleneck concerning low self-efficacy of numeracy and designed specific interventions to address both bottlenecks simultaneously. We implemented the proposed approach in an introductory level analytics course in business operations. Students who underwent the interventions successfully overcame both learning bottlenecks and indicated a positive change in attitude towards the analytics discipline as well as achieved higher exam scores in the analytics course.
\end{abstract}

Keywords: numeracy, problem-solving, learning bottleneck, Decoding the Discipline, theory of constraints, analytics education, workplace skills 


\section{Introduction}

As today’s business environment is increasingly shaped by globalization and technological advancements, a well-educated and skilled workforce that goes beyond reading and writing ability to possess quantitative information-processing skills, i.e., the ability to make complex decisions and solve problems involving quantitative information is in high demand, (Frank and Castek, 2017; Wilkins 2016, McClure and Sircar, 2008; Wilkins 2000). Indeed, past research indicated that quantitative information-processing skills are key cognitive and workplace skills needed for individuals to prosper and economies to grow in the next decade (Jonas, 2018; Martin, 2018; OECD, 2016). Recognizing that quantitative information-processing skills are imperative for individuals to succeed in the $21^{\text {st }}$ century society and global economy, the Organization for Economic Cooperation and Development (OECD) developed the Survey of Adults Skills via the Program for the International Assessment of Adult Competencies (PIACC) to assess the skills in two dimensions: numeracy, and problem-solving in technology-rich environments (PIACC, n.d.). According to PIACC, numeracy is "the ability to access, use, interpret, and communicate mathematical information and ideas, to engage in and manage mathematical demands of a range of situations in adult life”, and problem-solving in technologyrich environments is "the ability to use digital technology, communication tools, and networks to acquire and evaluate information, communicate with others, and perform practical tasks” (PIACC, n.d.). We will use the term quantitative information-processing skills and numeracy and problem-solving skills interchangeably whenever we mention these two dimensions in this paper.

Given that educational attainment positively relates to adults’ proficiency in numeracy and problem-solving (Rampey et al., 2016; OECD, 2013), and that these skills are best 
developed in academic settings (Pellegrino and Hilton, 2012), the focus has been how well our higher education institutions succeed in equipping college graduates with the skills needed to remain competitive in the increasingly complex technology-based global economy of the $21^{\text {st }}$ century. Many reports, however, indicate that the postsecondary system worldwide has fallen short in this aspect (U.S. Chamber of Commerce, 2016; Spellings 2012; Bridgeland et al., 2011; Casner-Lotto et al., 2009; Gordon, 2009; Council for Advancement of Adult Literacy, 2008). Nineteen percent of four-year college graduates in the U.S. have basic numeracy skill only (Baer et al., 2006), defined by Hauser et al. (2005) as "the skills necessary to perform simple and everyday literacy activities such as comparing ticket prices of two events”. About one in ten of university students in England have a numeracy level below level two (Kuczera et al., 2016), i.e., they have difficulty performing tasks involving calculations with whole numbers and common decimals, percents and fractions; or interpreting statistics in texts, tables, and graphics. A survey of 1,052 graduates and 907 employers in Spain found that problem-solving competency was highly sought by employers but not adequately acquired by graduates (Teijeiro et al., 2013). Employers in the U.S. and U.K. find their new hires are ill-prepared for the workplace skills required, especially proficiency in problem-solving (Shimshock, 2018; Vivian et al., 2018; NACE, 2017; Pew Research Center, 2016).

The skill deficiency in numeracy and problem-solving is disconcerting to educators, employers and educational policy makers. For educators, the deficiency means students are less prepared for university course work which adversely affects their academic performance and success (Joyce et al., 2017; Carpenter and Kirk, 2017; LeFevre et al, 2014). For employers, the deficiency means new hires are ill-prepared for knowledge work that demands high levels of problem-solving skills to sustain business growth and innovation (OECD, 2015; Barrett and 
Tolbert, 2014). For educational policy makers, the deficiency signals a need to shape policies that infuse $21^{\text {st }}$ century knowledge and skills into education so that students can be productive citizens of tomorrow (P21, 2008).

Given that business is the most popular college major (Torpey, 2016) and that business education directly addresses numeracy and problem-solving skills in preparing students for managerial professions (Snyder and Snyder, 2008), our attempt to redress the skill deficiency begins with undergraduate business students. As such, the primary objective of this paper is to investigate an educational approach to elevating the numeracy and problem-solving skills of undergraduate business students. We attempt to achieve this research objective by answering two research questions in this study:

(1) What are the barriers to improving undergraduate business students' numeracy and problem-solving skills?

(2) What is an effective approach to elevating numeracy and problem-solving skills in undergraduate business education?

We organize the rest of the paper as follows. We provide a review of extant literature on efforts put forth to elevate students' quantitative information-processing skills. Based on the literature review, we propose an education approach that is grounded in the theory of constraints (Goldratt, 1984) following the Decoding the Discipline model (Middendorf and Pace, 2004). We describe an empirical study to investigate a cognitive bottleneck involving quantitative modeling and an affective bottleneck concerning low self-efficacy of numeracy. We design specific interventions to address both the cognitive and affective bottlenecks. We report the effectiveness of the interventions in overcoming these learning bottlenecks and conclude our paper with a discussion of the study's findings, contributions, and limitations. 


\section{Literature Review}

Business educators find the skill deficiency reported above particularly challenging to address because a higher level of proficiency in numeracy and problem-solving is expected from business undergraduates, especially in many quantitative disciplines such as accounting, finance, economics, and analytics (Kremmer et al., 2010; De Lange et al., 2006). The numeracy and problem-solving skills required for business students goes beyond the basics. Principles of statistics, calculus, algebra, and optimization are some higher levels of mathematics knowledge needed for students to solve complex business decision problems objectively and to understand the intricate interrelationships among factors/variables impacting managerial decisions (McClure and Sircar, 2008). However, a significant number of students do not have adequate background in numeracy to meet the higher level of quantitative information-processing skills required in a business curriculum (Darroch and Rainsbury, 2009; Alcock et al., 2008; Standing et al., 2006; Ballard and Johnson, 2004). These students often find themselves struggling with the quantitative content in many introductory level core business courses, resulting in underperformance and dissatisfaction with the learning experience in their undergraduate business program (Aggarwal et al., 2007; Remington et al., 2000). Furthermore, students who do not possess a high level of quantitative information-processing skills will find themselves at a considerable disadvantage position in the $21^{\text {st }}$ century knowledge economy because graduates' numeracy and problem-solving proficiency determines their employability (Durrani and Tariq, 2012; Tariq et al., 2010; Jackson, 2010), economic success (Hanushek et al., 2017; Gaze, 2015), and also financial well-being and health (Jonas, 2018). As a result, students must raise their 
numeracy and problem-solving competency to meet the rigor of a business curriculum and workplace demand.

Attempts to improve students' numeracy and problem-solving skills suggest that overcoming barriers to skill development is the key to address skill deficiency. Recognizing students’ inadequate requisite quantitative competency as a cognitive barrier to skill development, a number of researchers have added a skill improvement core course in the business curriculum to boost students' quantitative information-processing skills (Pilling et al., 2012; Ganesh et al., 2010; McClure and Sircar, 2008). In addition, past research has attributed such affective factors as mathematics anxiety (Cronin and Carroll, 2015; Durrani and Tariq, 2009; Joyce and Hassall, 2006), negative attitude towards mathematics (Barkatsas et al., 2009; Papanastasiou, 2000), and low mathematical self-efficacy (Tariq et al., 2013; Tariq and Durrani, 2012) as obstacles hindering students’ numeracy and problem-solving skill development. However, recent studies that targeted affective barriers offered inconclusive results (Bhowmick et al., 2017; Tasari et al., 2012). While students' quantitative information-processing skills were increased, they also reported lower level of math self-concept (Tasari et al., 2012) and math selfefficacy (Brennan and Vos, 2013). As a result, we are considering a more holistic approach that simultaneously addresses both cognitive and affective barriers to skill development.

One such study that provides a systematic mechanism to identify and address barriers to skill development is the Decoding the Disciplines model (Middendorf and Pace, 2004). The model refers to the barriers as learning bottlenecks which are places in a course where students struggle to learn the material. The premise of the model is that experts and novices approach academic work differently because experts have mastered disciplinary-specific ways of thinking. Students develop experts' ways of thinking by following the modeled behavior to move through 
a learning bottleneck. This model has been adopted by faculty at Indiana University (Pace, 2004; Diaz et al., 2008) and reshaped a number of disciplines ranging from Astronomy (Durisen and Pilachowski, 2004) to Music History (Burkholder, 2011) to History (Middendorf et al., 2015) to Asian Studies (MacPherson, 2015) to Psychology (Pinnow, 2016).

While past studies reported success in applying the model in various disciplines, the theoretical basis of the model has not been fully explored (Pace and Middendorf, 2017). In addition, cognitive and affective bottlenecks need to be examined simultaneously instead of one at a time (Bhowmick et al., 2017). Furthermore, with the exception of Pinnow (2016), the effectiveness of the model has not been empirically examined. We attempt to fill these research gaps in this study by: (1) enriching the theoretical foundation of the model to strengthen the body of educational research in teaching and learning, (2) identifying and addressing both cognitive and affective barriers to skill development to offer a holistic conceptualization and treatment of learning bottlenecks, and (3) empirically investigate the effectiveness of the theoretically enhanced model in addressing skill deficiency.

\section{The Proposed Approach}

We propose an educational approach to elevate undergraduate business students’ numeracy and problem-solving competencies. The approach is an integration of the theory of constraints (Goldratt, 1984) and the Decoding the Disciplines model (Middendorf and Pace, 2004) with the intent to expand the theoretical basis of the model so that a goal-oriented process improvement perspective can be used to identify, analyze, and overcome bottlenecks/constraints of learning.

The Decoding the Disciplines model, as shown in Figure 1, is a seven-step process to create innovative learning interventions to overcome challenges in teaching and learning. 


\section{$* * * *$ Insert Figure 1 here $* * * *$}

The seven-step decoding process starts with step one: identifying the bottleneck to learning. A learning bottleneck is an area in a course where a significant number of students fail to learn, as exemplified by students’ inability to complete important learning tasks. The crux of step one depends on the instructor's ability to recognize and remove the learning bottleneck so that student learning can progress. Once a learning bottleneck is identified, step two: reconstructing the process of learning can occur whereby steps that come naturally to subject experts in getting past the learning bottleneck are delineated. This delineated process is then examined from the students’ perspective to gain an understanding of the students' thinking so that step three: modeling the process explicitly can take place. The intent of step three is to allow students to follow the ways experts used in overcoming the bottleneck. Step four: practicing the process of overcoming the bottleneck gives students means to try out the learning process and obtain feedback on their attempts at overcoming the learning bottleneck. Step five: motivating students to follow through with the process engages students in completing step three's modeling and step four's practicing phases of the decoding process. The effectiveness of the steps two through five is evaluated in step six: assessing student learning whereby evidence of students' mastery of the subject matter is gathered to gauge the success of overcoming the learning bottleneck. Depending on the outcome of step six, steps two through five may need to be reiterated. Finally, step seven: sharing the decoding experience allows a reflective examination of the entire process and dissemination of knowledge gained through this endeavor to others who have the same interest in teaching and learning improvements.

Goldratt proposed a similar pursuit of process improvement by eliminating bottlenecks in his theory of constraints (Goldratt, 1984). The theory of constraints posits that the limiting 
factor in preventing any system from achieving its goal is a constraint or bottleneck. By analyzing the process involved in reaching the goal of a system, the constraint can be identified and managed as a continuous improvement loop, as shown in Figure 2.

\section{**** Insert Figure 2 here $* * * *$}

According to the theory of constraints, the six-step process improvement begins with step one: identify the constraint. The first step takes a system view of the entire process with the intent to reveal the weakest link of the system that compromises the system's ability to attain its goal. The constraint identified is passed onto step two: exploit the constraint to ensure that the constraint is a necessary part of the process. The second step is followed by step three: subordinate all other processes to the constraint so that all processes involved in the system are aligned with its goal. The goal alignment enables step four: elevate the constraint to take place to eliminate the obstacle that prevents the system from reaching its goal. Step five: identify a new constraint returns the process to step one in order for step six: engage in continuous improvement to repeat the above steps as a never-ending process.

The six steps proposed by Goldratt's theory of constraints give a goal-oriented continuous process improvement perspective that enhances the Decoding the Discipline model. The goal-oriented emphasis puts a focus on a learning goal to guide the process of learning improvement in three steps: (1) identify the bottleneck/constraint where performance of learning tasks does not measure up to the learning goal, (2) create learning interventions as ways to close the performance gap, and (3) assess learning outcomes to ensure learning performance is aligned with the learning goal. In other words, when combining the two, we are advocating a process approach to learning enhancements whereby continual improvements and manageable interventions can be effectively introduced with an integral focus on identifying learning 
bottlenecks, creating learning interventions, and assessing learning outcomes. Figure 3 delineates the three steps involved in overcoming learning bottlenecks as constraints of a learning process.

\section{**** Insert Figure 3 here}

\section{Empirical Study}

We applied the approach described above to elevate students' numeracy and problemsolving competencies by addressing two bottlenecks in an undergraduate core course in analytics called Analyzing Business Operations. The course studies quantitative and technology-based analytical techniques for managing an organization's manufacturing and/or service operations.

\section{Cognitive bottleneck}

Equipping students with problem-solving skills has been repeatedly the most challenging goal to achieve in this course. A major bottleneck of learning problem-solving skills is that students have difficulty understanding how to build models to solve business decision problems (Step 1: identify a learning bottleneck). The critical process of identifying various factors affecting a decision problem and expressing the relationships among these factors is often bypassed. As a result, students regard solving a business problem as nothing more than putting numbers into a magic black box called a "model". There appears to be little interest in understanding how the model is derived, how to interpret the "answer" from the black box, and how to extend the model to represent more complex situations.

To get past this bottleneck, the quantitative modeling process was compared to learning English (or any language) - a subject matter familiar to all students. The intellectual process of quantitative modeling could be followed in a similar fashion as in linguistics whereby choosing 
the right building blocks in mathematics (e.g., variables, constants, and operators) was akin to finding the right alphabets, words, and phrases in English so that the business problem could be described using mathematical building blocks as algebraic expressions of factors affecting the business problem. This modeling process was demonstrated to the students throughout the course. Students practiced the process through homework, quizzes, assignments, and exams throughout the course from productivity analyses to optimization using linear programming (Step 2: create a learning intervention). Their model building process was assessed in all exams. An explicit statement, "Numerical answers must be accompanied by indications of how your answers were derived to receive partial credit." is placed on the cover page of each exam to remind students of the importance of documenting their modeling process. Partial credit was given to wrong answers to multiple choice questions if the modeling process was correctly shown alongside the question. The effectiveness of the intervention is assessed by the exam scores and a survey (Step 3: assess learning outcomes).

\section{Affective bottleneck}

Another challenge of this course is the affective bottleneck. Students have a mistaken pre-conception that the course is demanding. This coupled with students' low self-efficacy in numeracy presents an obstacle to keeping students stimulated and interested in learning the course contents (Step 1: identify a learning bottleneck).

To dispel the misconception of the course of being demanding, the usefulness of the subject matter was demonstrated through two levels of applications - both personal and business. Students were shown how different business operations concepts such as productivity and quality control were relevant and applicable to both their personal and professional lives. They were then asked to write about such applications in a course blog. To motivate students to raise their 
numeracy competencies, evidence of the importance of mathematical thinking - from the fun of manipulating numbers with EXCEL as a tool to the strong demand of numeracy skills in the job market - were discussed throughout the course (Step 2: create a learning intervention). As with the cognitive bottleneck, the effectiveness of the intervention was assessed by exam scores and a survey (Step 3: assessing learning outcomes). Table 1 summarizes our proposed approach described in Figure 3.

\section{**** Insert Table 1 here $* * * *$}

\section{Methodology}

The analytics course provides an ideal natural setting for the current study because of its emphasis on quantitative reasoning using technological tools to solve operations related problems. The same instructor taught the course in two consecutive summer and fall terms using the same lesson plan, assessment methods, and instructional methods except that the cognitive and affective learning interventions were introduced in the most recent summer and fall terms.

We evaluated the effectiveness of the proposed approach using both subjective and objective assessments. Students' self-reported perceptions of the learning experience with the interventions were the basis of the subjective assessment. Students' exam scores were used as a proxy measure for their actual learning in the objective assessment. Exam scores were compared between classes with and without the interventions in their respective summer and fall terms.

We used a survey at the end of the course to evaluate the perceived effectiveness of the cognitive and affective learning interventions. The survey was designed to capture students’ perception of their attitude of the course and their assessment and long-term impacts of the cognitive and affective learning interventions. We administered the survey twice: round one on 
twenty-eight students taking the course in the summer and round two on fifty five students taking the course in the fall.

The survey was divided into two parts, as shown in Appendix A. Part one had nine questions asking for students' background information including hours spent outside class time per day on the course, major, working hours, classification, required/elective course, physical disability, expected grade, before and after opinions of the course. Part two had twelve statements on assessing the effectiveness of the proposed approach using a scale of 1 (strongly disagree) to 5 (strongly agree). Four statements were used to evaluate the effectiveness of the cognitive bottleneck intervention: (1) I find it difficult to explain how my answers are derived, (2) I find it difficult to reason objectively, (3) I find it difficult to articulate the problem-solving process, and (4) I find it difficult to apply what I learned to more complex situations. Four statements were used to measure the effectiveness of the affective bottleneck intervention: (1) I find it difficult to use EXCEL, (2) I find it distracting to have in-class computer access, (3) I find it difficult to think quantitatively, (4) I find it frustrating not getting the right answer. Four statements were used to gauge the long term impacts of the proposed approach: (1) I want to further my mastery of EXCEL, (2) I want to further my quantitative thinking capacity, (3) I want to further my problem-solving skill, and (4) I want to further my fact-based decision making skill.

To further investigate the effectiveness of the proposed approach beyond self-reporting, we evaluated the impact of the interventions on actual learning by comparing the exam scores between classes with and without the interventions. We conducted the score comparison twice: first for the summer and second for the fall classes to avoid confounding the exam scores with differences in demographics between summer and fall students. Both times the overall exam 
score was compared between classes with and without the interventions using an independent samples t-test.

\section{Findings}

The survey result shows that students in both rounds took the course as required in their senior year. Over $90 \%$ of them did not have physical disability. They also expected to earn a grade of B or above in the course although more students in round two expected to earn an A grade. In addition, those in round one spent less time on the course, were not all business majors, and worked five times more than those in round two, as shown in Table 2. This was expected since round one was conducted during the summer when students often held summer jobs and the course was more accessible to non-business majors.

\section{**** Insert Table 2 here $* * * *$}

Despite some differences in students' demographics, survey results of the cognitive bottleneck intervention from both rounds consistently showed that students found it was not difficult to explain how answers were derived. They indicated it was not difficult to reason objectively, with round one reporting less difficulty than round two. They also were able to articulate the problem-solving process with ease and apply what they learned to more complex situations. All four statements received an average score of 3 or less out of 5 on a Likert scale of 1 to 5 with 1 indicating highly easy. In addition, all of them indicated a strong desire to further their problem-solving and fact-based decision making skills, (all these statements received an average score above 3.8 out of 5). Therefore, the efforts made to overcome the cognitive bottleneck of quantitative modeling were deemed a success.

Regarding the effectiveness of the affective bottleneck intervention, students found using EXCEL and in-class computers improved their learning experience. They also indicated it was 
not difficult to think quantitatively. In fact, students in round one reported less difficulty in quantitative thinking than those in round two. All three statements received an average score of 3 or less out of 5 on a Likert scale of 1 to 5 with 1 indicating highly easy. Although students still found that it was frustrating not getting the right answer (the average score was 3 out of 5 and 3.8 out of 5 in rounds 1 and 2 respectively), the fact that all of them indicated a strong desire to further their quantitative thinking capacity and mastery of EXCEL (all these statements received an average score above 3.3 out of 5), the affective bottleneck was effective in raising students' self-efficacy of numeracy competencies.

More importantly, survey results from both rounds indicated a positive change in attitude towards the analytics discipline. The before and after opinions of analytics in round one had an average rating of 2.7 and 3.3 respectively on a Likert scale of 1 to 5 with 1 indicating poor. On the other hand, the before and after opinions of analytics in round two had an average rating of 2.8 and 3.5 respectively. The higher rating of the after opinion was statistically significant (t-test with $\mathrm{p}<0.05)$. The above findings, as shown in Table 3, lend support to the viability of learning interventions implemented to address both cognitive and affective bottlenecks in raising students' numeracy and problem-solving competencies.

\section{**** Insert Table 3 here $* * * *$}

To further examine the impact of the interventions on actual learning outcome, we used an independent t-test to compare the differences between students' exam scores in classes with and without the interventions. Since students' demographics in summer and fall classes were not identical, two rounds of exam score comparisons are performed: one for the summer and the other for the fall classes. The t-test results from both rounds consistently showed that students scored statistically significant higher on their exams in classes with the intervention than those without the interventions, as shown in Table 4. Specifically, students in the intervened summer 
class had higher exam scores than students in the non-intervened class, $\mathrm{t}(71)=4.7, \mathrm{p}=0.000$.

Similarly, students in the intervened fall class scored higher in their exams than those in the nonintervened class, $\mathrm{t}(103)=3.4, \mathrm{p}=0.001$.

\section{**** Insert Table 4 here}

\section{Discussion}

We set out to seek answers to two research questions: (1) What are the barriers to improving undergraduate business students’ numeracy and problem-solving skills? and (2) What is an effective approach to elevating numeracy and problem-solving skills in undergraduate business education? A short answer to these questions is that our proposed approach is effective in overcoming both cognitive and affective bottlenecks simultaneously to improve students' numeracy and problem-solving skills through mastery of quantitative modeling and a positive change in attitude towards the analytics discipline.

Our study has both theoretical and practical contributions. From a theoretical point of view, we extend the theory of constraints to analyze the process of learning and to enrich the theoretical foundation of the Decoding the Discipline model. The resulting approach to learning improvement is simpler and also easier to understand and implement. It involves three steps: (1) identify learning bottlenecks as constraints that prevent learners from reaching a learning goal, (2) create learning interventions that align learning outcomes with the learning goal, and (3) assess learning outcomes to determine successful attainment of the learning goal. Our approach also offers a holistic conceptualization of cognitive and affective learning bottlenecks to successfully overcome both bottlenecks simultaneously.

In regard to practical contributions, we provide empirical evidence to support the effectiveness of our proposed approach in addressing skill deficiency by simultaneously 
identifying and addressing cognitive and affective barriers to skill development. The cognitive intervention is demonstrated to better enable students to articulate the quantitative modeling process in problem-solving. At the same time, the affective intervention is shown to raise students' self-efficacy in numeracy so that they are more inclined to think mathematically with the use of the proper tools to arrive at a right solution. All together, students who underwent the interventions successfully show a positive change in attitude towards the analytics discipline and achieving higher exam scores in the analytics course. As a result, our proposed approach is useful for educators in general and business faculty in particular to improve students' quantitative modeling skill and attitude. Researchers can also extend our approach to other courses and settings to build up the body of research in learning and skill development. In addition, educational policy makers may want to consider promoting promising approaches to improve students’ quantitative skill development such as ours through symposia, conferences, faculty learning communities, and workshops. They can also set a high standard for higher education institutions to assess students’ numeracy and problem-solving competencies.

As students’ numeracy and problem-solving skills are raised, they will develop an aptitude for quantitative-oriented coursework that equips them with the set of quantitative information-processing skills needed to succeed in the $21^{\text {st }}$ century society and global economy. Employers will find college graduates bring to their initial positions the high levels of numeracy and problem-solving skills demanded for knowledge work to sustain business growth and innovation. In short, our proposed approach demonstrates the potential of innovative pedagogical tools for quantitative information-processing skills to address the skill-gap concerns of educators, employers, and educational policy makers. 
The study has several limitations. First, we implemented and assessed the proposed approach in one analytics course. The findings should be interpreted with caution in different courses and settings, e.g., non-quantitative disciplines such as fine arts where creativity may be more of a constraint than quantitative reasoning. Second, we do not address creative problemsolving in an ill-structured context in the study. Third, the explanatory power of the study is limited as factors that may account for the change in skill level (e.g., other courses that were taken simultaneously) are not taken into consideration in the analysis. Finally, the survey instrument needs to be validated further beyond its face-value to confirm its reliability.

Despite the limitations described above, researchers can build on findings reported here to further our understanding of how to identify and address learning bottlenecks in skill development. Promising avenues of investigation include:

1. A further testing of the proposed approach in arts and science disciplines to generalize the study's findings to different courses and settings.

2. An adaption of the proposed approach for creative problem-solving in real-life contexts to shed light on how best to develop problem-solving skill in unstructured context.

3. An experimentation of the proposed approach in controlled and treatment settings to provide a causal explanation of cognitive and affective factors in developing numeracy and problem-solving competencies.

4. A validated survey instrument for cognitive and affective learning intervention assessments with strong construct validity, reliability, and internal consistency. 


\section{Conclusion}

Our proposed approach provides a structured process to teaching and learning enhancement to improve learning outcomes. The integral focus on identifying learning bottlenecks, creating learning interventions, and assessing learning outcomes in our proposed approach is instrumental in introducing manageable interventions to address challenges in student learning thereby elevating students’ numeracy and problem-solving competencies so that they are better equipped with workplace skills. Analyses of the study’s results gave empirical support to the effectiveness of the proposed approach to overcoming cognitive and affective bottlenecks in learning. More research is needed to address the limitations of the study. Future research is planned to investigate the effectiveness of the proposed approach to meeting the challenges of teaching the course in both an online and a large section of hundreds of students in upcoming semesters. 


\section{References}

Alcock, J., Cockcroft, S., and Finn, F. (2008), "Quantifying the Advantage of Secondary Mathematics Study for Accounting and Finance Undergraduates. Accounting and Finance”, Vol. 48, No. 5, pp.697-718.

Aggarwal, P., Vaidyanathan, R., and Rochford, L. (2007), "The Wretched Refuse of a Teeming Shore? A Critical Examination of the Quality of Undergraduate Marketing Students", Journal of Marketing Education, Vol. 29, No. 3, pp.223-233.

Baer, J.D., Cook, A.L., \& Baldi, S. (2006), “The Literacy of America’s College Students. American Institutes for Research", Washington, D.C., available at: http://www.air.org/files/The20Literacy20of20Americas20College20Students_final20report.pdf (accessed 27 March 2018).

Ballard, C.L, and Johnson, M.F. (2004), "Basic Math Skills and Performance in an Introductory Economics Class”, The Journal of Economic Education, Vol. 35, No. 1, pp.3-23.

Barkatsas, A., Kasimatis, K. and Gialamas, V. (2009), "Learning Secondary Mathematics with Technology: Exploring the Complex Interrelationship Between Students’ Attitudes, Engagement, Gender and Achievement”, Computers and Education, Vol. 52, No. 3, pp.562-570.

Barrett, R.T., and Tolbert, S.H. (2014), "Problem Solving in the Workplace through Application of Business Knowledge and Quantitative Methods”, Journal of Business and Economics, 5(7), pp.937-944.

Bhowmick, S., Young, J.A., Clark, P.W., and Bhowmick, N. (2017), “Marketing Students’ Mathematics Performance: The Mediating Role of Math Anxiety on Math Self-Concept and Math Self-Efficacy”, Journal of Higher Education Theory and Practice, Vol. 17, No. 9, pp.104117.

Brennan, R., and Vos, L. (2013), "Effects of Participation in a Simulation Game on Marketing Students' Numeracy and Financial Skills”, Journal of Marketing Education, Vol. 35, No. 3, pp.259-270.

Bridgeland, J., Milano, J., and Rosenblum, E. (2011), “Across the Great Divide: Perspectives of CEOs and College Presidents on America's Higher Education and Skills Gap”, available at: https://files.eric.ed.gov/fulltext/ED518231.pdf (accessed 27 September 2018)

Burkholder, J.P. (2011), “Decoding the Discipline of Music History for Our Students”, Journal of Music History Pedagogy, Vol. 1, No. 2, pp. 93-111.

Carpenter, T.P., and Kirk, R.E. (2017). “Are Psychology Students Getting Worse at Math?: Trends in the Math skills of Psychology Statistics Students Across 21 Years”, Education Studies, Vol. 43, No. 3, pp.282-295. 
Casner-Lotto, J., \& Barrington, L. (2006). “Are they really ready to Work? Partnership for 21st century skills”, available at: http://www.p21.org/storage/documents/

FINAL_REPORT_PDF09-29-06.pdf (accessed 27 September 2018).

Council for Advancement of Adult Literacy (2008), "Reach Higher, America: Overcoming Crisis in the U.S. Workforce”, Report of the National Commission on Adult Literacy, New York, NY.

Cronin, A., and Carroll, P. (2015), “Engaging Business Students in Quantitative Skills Development”, e-Journal of Business Education \& Scholarship of Teaching, Vol. 9, No. 1, pp.119-131.

Darroch, A., and Rainsbury, E. (2009), "When Perception Meets reality: Helping Students Understand Their need for Learning Support in a First-year Accountancy Course”, The Student Experience, Proceedings of the 32nd HERDSA Annual Conference, Darwin: Australia, 6-9 July, pp.561-566.

De Lange, P., Jackling, B., and Gut, A. (2006), “Accounting Graduates’ Perceptions of Skills Emphasis in Undergraduate Courses: an Investigation from Two Victorian Universities”, Accounting and Finance, Vol. 46, No. 3, pp.365-386.

Diaz, A., Middendorf, J., Pace, D., and Shopkow, L. (2008), “The History Learning Project: a Department 'Decodes’ its Students”, The Journal of American History, Vol. 94, No. 4, pp. 12111224.

Durisen, R.H, and Pilachowski, C.A. (2004), "Decoding Astronomical Concepts”, New Directions for Teaching and Learning, Vol. 2004, No. 98, pp.33-43.

Durrani, N., and Tariq, V.N. (2012), “The Role of Numeracy Skills in Graduate Employability”, Education + Training, 54(5), pp.419-434.

Durrani, N., and Tariq. V.N. (2009), “Relationship Between Undergraduates’ Mathematics Anxiety and Their Attitudes Towards Developing Numeracy Skills and Perceptions of Numerical Competence”, Proceeding of ICERI 2009 Conference, Madrid, Spain, 16-18 November, pp.787-794.

Frank, T.H.J., and Castek, J. (2017), "From Digital Literacies to Digital Problem Solving: Expanding Technology-rich Learning Opportunities for Adults”, Journal of Research and Practice for Adult Literacy, Secondary, and Basic Education, Vol. 6, No. 2, pp.66-70.

Ganesh, G., Sun, Q., and Barat, S. (2010), “Improving the Marketing Math Skills of Marketing Undergraduate Students Through a Unique Undergraduate Marketing Math Course”, Marketing Education Review, Vol. 20, No. 1, pp.47-63.

Gaze, E. (2015), “Addressing the Skills Gap for Students and Young Adults”, Diverse, July 2, pp.24. 
Goldratt, E.M. (1984), The Goal: A Process of Ongoing Improvement, North River Press, Great Barrington, MA.

Gordon, E. (2009), The Global Talent Crisis. The Futurist, Vol. 43, No. 5, pp.34-39.

Hanushek, E.A., Schwerdt, G., Wiederhold, S., and Woessmann, L. (2017), “Coping with Change: International Differences in the Returns to Skills”. Economics Letters, Vol. 153, No. 4, pp.15-19.

Hauser, R.M., Edley, C.F. Jr., Koenig, J.A., \& Elliott, S.W. (Eds.). (2005), "Measuring Literacy: Performance Levels for Adults”, Interim Report, The National Academies Press, Washington, D.C.

Jackson, D. (2010), “An International Profile of Industry-relevant Competencies and Skill Gaps in Modern Graduates”, International Journal of Management Education, Vol. 8, No. 3, pp.29-58.

Jonas, N. (2018), “Numeracy Practices and Numeracy Skills Among Adults”, OECD Education Working Papers, No. 177, OECD Publishing, Paris.

Joyce, C., Hine, G., and Anderton, R. (2017), “The Association Between Secondary Mathematics and First Year University Performance in Health Sciences”, Issues in Education Research, Vol. 27, No. 4, pp.770-783.

Joyce, J., and Hassall, T. (2006), “Communication Apprehension and Maths Anxiety as Barriers to Communication and Numeracy Skills Development in Accounting and Business Education”, Education + Training, Vol. 48, No. 6, pp.454-464.

Kremmer, M., Brimble, M., Freudenberg, B., and Cameron, C. (2010), "Numeracy of First Year Commerce Students: Preliminary Analysis of an Intervention”, The International Journal of Learning, Vol. 17, No. 1, pp.1-13.

Kuczera, M., Field, S., and Windisch, H.C. (2016), "Building Skills For All: A Review of England”, OECD Skills Studies, OECD Publishing, Paris, available at: https://ec.europa.eu/epale/sites/epale/files/building-skills-for-all-review-of-england.pdf (accessed January 8, 2019).

LeFevre, J., Penner-Wilger, M., Pyke, A.A., Shanahan, T., and Deslauriers, W.A. (2014), "Putting Two and Two Together: Declines in Arithmetic Fluency among Young Canadian Adults, 1993 to 2005”, Carleton University Cognitive Science Technical Report 2014-01, Institute of Cognitive Science and Department of Psychology, Carleton University, Ottawa: ON.

MacPherson, K.R. (2015), “Decoding Area Studies and Interdisciplinary Majors: Building a Framework for Entry-Level Students”, College Teaching, Vol. 63, No. 2, pp. 40-45. 
Martin, J.P. (2018), “Skills for the $21^{\text {st }}$ Century: Findings and Policy Lessons from the OECD Survey of Adult Skills”, IZA Policy Paper, No. 138, Institute of Labor Economics, Bonn, Germany.

McClure, R., and Sircar, S. (2008), “Quantitative Literacy for Undergraduate Business Students in the $21^{\text {st }}$ Century”, Journal of Education for Business, Vol. 83, No. 6, pp. 369-374.

Middendorf, J., and Pace, D. (2004), "Decoding the Disciplines: A Model for Helping Students Learn Disciplinary Ways of Thinking”, New Directions for Teaching and Learning, Vol. 2004, No. 98, pp. 1-12.

Middendorf, J., Mickute, J., Saunders, T., Najar, J., Clark-Huckstep, A.E., Pace, D, Eberly, K., and McGrath, N. (2015), "What's Feeling Got To Do With it? Decoding Emotional Bottlenecks in the History Classroom”, Arts \& Humanities in Higher Education, Vol. 14, No. 2, pp. 166-180.

NACE (2017), “The Key Attributes Employers Seek on Students’ Resumes. The National Association of Colleges and Employers”, NACE, Bethlehem, PA, available at: http://www.naceweb.org/about-us/press/2017/the-key-attributes-employers-seek-on-studentsresumes/ (accessed 27 September 2018).

OECD (2016), “Skills Matter: Further Results from the Survey of Adult Skills”, OECD Skills Studies, OECD Publishing, Paris, available at: https://doi.org/10.1787/9789264258051-en (accessed 27 September 2018).

OECD (2015), “Adults, Computers and Problem Solving: What's the Problem?”, OECD Skills Studies, OECD Publishing, Paris, available at: https://doi.org/10.1787/9789264236844-en (accessed 27 September 2018).

OECD (2013), “OECD Skills Outlook 2013: First Results from the Survey of Adult Skills”, OECD Publishing. Paris, available at: http://dx.doi.org/10.1787/9789264204256-en (accessed 27 September 2018).

Pace, D. (2004), “Decoding the Reading of History: An Example of the Process”, New Directions for Teaching and Learning, Vol. 2004, No. 98, pp.13-21.

Pace, D., and Middendorf, J. (2017). “Forward”, New Directions for Teaching and Learning, Vol. 2017, No. 150, pp.9-11

Papanastasiou, C. (2000), "Effects of Attitudes and Beliefs on Mathematics Achievement”, Studies in Educational Evaluation, Vol. 26, No.1, pp.27-42.

Pilling, B. K., Rigdon, E. E., \& Brightman, H. J. (2012), “Building a metrics-enabled marketing curriculum: The cornerstone course”, Journal of Marketing Education, Vol. 34, No. 2, pp.179193. 
Pellegrino, J.W., and Hilton, M.J. (2012), “Education for Life and Work: Developing Transferable Knowledge and Skills in the 21st Century”, Washington, DC: The National Academies Press.

Pew Research Center (2016), “The State of American Jobs”, available at: http://www.pewsocialtrends.org/2016/10/06/the-state-of-american-jobs/ (accessed 27 September 2018).

P21 (2008), “ $21^{\text {st }}$ Century Skills, Education \& Competitiveness: a Resource and Policy Guide”, Tucson, AZ: Partnership for $21^{\text {st }}$ Century Skills.

PIAAC (n.d.), “The Program for the International Assessment of Adult Competencies”, National Center for Education Statistics, the Institute of Education Sciences, U.S. Department of Education, Washington, D.C., available at: http://nces.ed.gov/surveys/piaac/index.asp (accessed 27 September 2018).

Pinnow, E. (2016), “Decoding the Disciplines: An Approach to Scientific Thinking”, Psychology Learning \& Teaching, Vol.15, No.1, pp. 94-106.

Rampey, B.D., Finnegan, R., Goodman, M., Mohadjer, L., Krenzke, T., Hogan, J., and Provasnik, S. (2016), "Skills of U.S. Unemployed, Young, and Older Adults in Sharper Focus: Results From the Program for the International Assessment of Adult Competencies (PIAAC) 2012/2014: First Look (NCES 2016-039rev)”, National Center for Education Statistics, U.S. Department of Education. Washington, D.C.

Remington, S., Guidry, J. A., Budden, M. C., \& Tanner, J. R. (2000), "When Were the Good Old Days? Revisiting Perceptions of Marketing Students’ Prior Preparation”, Journal of Marketing Education, Vol. 22, No. 3, pp.188-198.

Standing, L.G., Sproule, R.A., and Leung, A. (2006), “Can Business and Economics Students Perform Elementary Arithmetic”, Psychological Report, Vol. 98, No. 2, pp.549-555.

Shimshock, R. (2018). Study: Half of Employers Don’t Think College Prepares Students for Work, The Daily Caller, The Daily Caller News Foundation, Washington, D.C., available at: http://dailycaller.com/2018/05/02/college-prepare-students-for-work/ (accessed 27 September 2018).

Spellings, M. (2012), “The Jobs Are There, The Education Is Not”, USA Today, 20 September, available at: http://www.usatoday.com/story/opinion/2012/09/20/jobs-educationunemployment/1583841/ (accessed 27 September 2018).

Snyder, L.G., and Snyder, M.J. (2008), “Teaching Critical Thinking and Problem Solving Skills”, The Delta Pi Epsilon Journal, Vol. 1, No, 2, pp.90-99.

Tariq, V.N., Qualter, P., Roberts, S., Appleby, Y., and Barnes, L. (2013), “Mathematical Literacy in Undergraduates: Role of gender, Emotional Intelligence and Emotional Self- 
efficacy”, International Journal of Mathematical Education in Science and Technology, Vol. 44, No. 8, pp.1143-1159.

Tariq, V.N., and Durrani, N. (2012), “Factors Influencing Undergraduates’ Self-evaluation of Numerical Competence”, International Journal of Mathematical Education in Science and Technology, Vol. 43, No. 3, pp.337-356.

Tariq, V.N., Durrani, N., Lloyd-Jones, R., Nicholls, D., Timmins, J.G., and Worthington, C.H. (2010), “Every Student Counts: Promoting Numeracy and Enhancing Employability”, Final Report. University of Central Lancashire, Lancashire, United Kingdom, available at: http://clok.uclan.ac.uk/5347/1/5347_Vicky\%20Tariq_Every\%20Student\%20Counts.pdf (accessed 27 September 2018)

Tasari, C.O., Wilson, J.H., Puri, C., and Divine, R.L. (2012), “Affinity for Quantitative Tools: Understanding Marketing Students Moving Beyond Quantitative Anxiety”, Journal of Marketing Education, Vol. 35, No. 1, pp.41-53.

Teijeiro, M., Rungo, P., and Freire, M.J. (2013), “Graduate Competencies and Employability: the Impact of Matching Firms' Needs and Personal Attainment”, Economics of Education Review, Vol. 34, No. 6, pp.286-295.

Torpey, E. (2016), “Business Careers with High Pay,” Career Outlook, Bureau of Labor Statistics, U.S. Department of Labor, Washington, D.C., available at: http://www.bls.gov/careeroutlook/2016/article/high-paying-business-careers.htm (accessed 27 September 2018).

Vivian, D., Winterbotham, M, Shury, J., James, A.S., Hewitt, J.H., Tweddle, M,, and Downng, C. (2018), "Employer Skills Survey 2015: UK Results”, UK Commission for Employment and Skills, London, available at:

https://assets.publishing.service.gov.uk/government/uploads/system/uploads/attachment_data/file /704104/Employer_Skills_Survey_2015_UK_Results-Amended-2018.pdf (accessed 27

September 2018)

U.S. Chamber of Commerce (2016), "Dear 45: Ensure Postsecondary Education Responds to Employer Needs”, available at: https://www.uschamber.com/above-the-fold/dear-45-ensurepostsecondary-education-responds-employer-needs (accessed 27 September 2018).

Wilkins, J.L.M. (2000), "Preparing for the $21^{\text {st }}$ Century: the Status of Quantitative Literacy in the United States,” School Science and Mathematics, Vol. 100, No. 8, pp. 405-418.

Wilkins, J.L.M. (2016), “An Assessment of the Quantitative Literacy of Undergraduate Students”, The Journal of Experimental Education, Vol. 84, No. 4, pp. 639-665. 


\section{APPENDIX A}

This survey is designed to gather your opinion on your learning experience in this course. Please answer the following questions thoughtfully and with as much detail as possible.

PART I. Background Information

\begin{tabular}{|c|c|c|c|c|c|c|}
\hline & $\begin{array}{l}\text { How many hours per day have } \\
\text { you been spending on this course } \\
\text { (excluding class time)? }\end{array}$ & $<1$ & 2 & 3 & 4 & $>4$ \\
\hline 2. & What is your major? & & & & & \\
\hline & Are you working? & No & \multicolumn{2}{|c|}{ Yes, I am working [ } & \multicolumn{2}{|c|}{ ] hours per week } \\
\hline & $\begin{array}{l}\text { What is your student } \\
\text { classification? }\end{array}$ & Freshman & Sophomore & Junior & Senior & Graduate \\
\hline 5. & Is this a required course? & Yes & \multicolumn{4}{|c|}{ No, I am taking this to } \\
\hline & $\begin{array}{l}\text { Do you have any physical } \\
\text { disability? }\end{array}$ & No & \multicolumn{4}{|c|}{ Yes, I have } \\
\hline & $\begin{array}{l}\text { What grade do you expect to } \\
\text { earn in this course? }\end{array}$ & A & B & C & $\mathrm{D}$ & E \\
\hline & $\begin{array}{l}\text { What is your opinion of Analytics } \\
\text { before taking this course? }\end{array}$ & Poor-1 & 2 & 3 & 4 & 5-Good \\
\hline & $\begin{array}{l}\text { What is your opinion of Analytics } \\
\text { after taking this course? }\end{array}$ & Poor-1 & 2 & 3 & 4 & 5-Good \\
\hline
\end{tabular}

\section{PART II. Learning Experience}

Please indicate to what extent each of the following statements describes your learning experience after taking the course.

\begin{tabular}{|c|c|c|c|c|c|}
\hline $\begin{array}{l}\text { 1. I find it difficult to explain how my answers are } \\
\text { derived }\end{array}$ & $\begin{array}{l}\text { 1-Strongly } \\
\text { Disagree }\end{array}$ & 2 & 3 & 4 & $\begin{array}{l}\text { 5-Strongly } \\
\text { Agree }\end{array}$ \\
\hline 2. I find it difficult to think quantitatively & $\begin{array}{l}\text { 1-Strongly } \\
\text { Disagree }\end{array}$ & 2 & 3 & 4 & $\begin{array}{l}\text { 5-Strongly } \\
\text { Agree }\end{array}$ \\
\hline 3. I find it difficult to use Excel & $\begin{array}{l}\text { 1-Strongly } \\
\text { Disagree }\end{array}$ & 2 & 3 & 4 & $\begin{array}{l}\text { 5-Strongly } \\
\text { Agree }\end{array}$ \\
\hline 4. I find it distracting to have in-class computer access & $\begin{array}{l}\text { 1-Strongly } \\
\text { Disagree }\end{array}$ & 2 & 3 & 4 & $\begin{array}{l}\text { 5-Strongly } \\
\text { Agree }\end{array}$ \\
\hline 5. I find it difficult to reason objectively & $\begin{array}{l}\text { 1-Strongly } \\
\text { Disagree }\end{array}$ & 2 & 3 & 4 & $\begin{array}{l}\text { 5-Strongly } \\
\text { Agree }\end{array}$ \\
\hline $\begin{array}{l}\text { 6. I find it difficult to articulate the problem solving } \\
\text { process }\end{array}$ & $\begin{array}{l}\text { 1-Strongly } \\
\text { Disagree }\end{array}$ & 2 & 3 & 4 & $\begin{array}{l}\text { 5-Strongly } \\
\text { Agree }\end{array}$ \\
\hline $\begin{array}{l}\text { 7. I find it difficult to apply what I learned to more } \\
\text { complex situations }\end{array}$ & $\begin{array}{l}\text { 1-Strongly } \\
\text { Disagree }\end{array}$ & 2 & 3 & 4 & $\begin{array}{l}\text { 5-Strongly } \\
\text { Agree }\end{array}$ \\
\hline 8. I find it frustrating not getting the right answer & $\begin{array}{l}\text { 1-Strongly } \\
\text { Disagree }\end{array}$ & 2 & 3 & 4 & $\begin{array}{l}\text { 5-Strongly } \\
\text { Agree }\end{array}$ \\
\hline 9. I want to further my mastery of Excel & $\begin{array}{l}\text { 1-Strongly } \\
\text { Disagree }\end{array}$ & 2 & 3 & 4 & $\begin{array}{l}\text { 5-Strongly } \\
\text { Agree }\end{array}$ \\
\hline 10. I want to further my quantitative thinking capacity & $\begin{array}{l}\text { 1-Strongly } \\
\text { Disagree }\end{array}$ & 2 & 3 & 4 & $\begin{array}{l}\text { 5-Strongly } \\
\text { Agree }\end{array}$ \\
\hline 11. I want to further my problem solving skill & $\begin{array}{l}\text { 1-Strongly } \\
\text { Disagree }\end{array}$ & 2 & 3 & 4 & $\begin{array}{l}\text { 5-Strongly } \\
\text { Agree }\end{array}$ \\
\hline 12. I want to further my fact-based decision making skill & $\begin{array}{l}\text { 1-Strongly } \\
\text { Disagree }\end{array}$ & 2 & 3 & 4 & $\begin{array}{l}\text { 5-Strongly } \\
\text { Agree }\end{array}$ \\
\hline
\end{tabular}

